\title{
RESEARCH
}

Open Access

\section{Factors associated with access to health care among foreign residents living in Aichi Prefecture, Japan: secondary data analysis}

\author{
Michiyo Higuchi $^{1 *}$ D, Maki Endo ${ }^{2}$ and Asako Yoshino ${ }^{1}$
}

\begin{abstract}
Background: In Japan, foreign residents, and particularly new arrivals in the country, experience barriers to health care and show poorer health outcomes when compared to Japanese nationals. The health-care-related situation for foreign residents in Japan has been characterized by drastic changes over time; thus, there is difficulty identifying individuals who are "left behind" by the system. In this study, we aimed to identify, among foreign residents who attended informal free medical consultations, factors associated with "being advised to visit a medical facility" and "being referred to a medical facility," which represented hypothetical proxy indicators of barriers to health care.

Methods: Secondary data analyses were conducted using the activity records of a non-governmental organization that provides free consultations targeting foreign residents in various locations in Aichi Prefecture, Japan. Participant characteristics, including insurance coverage, were determined. Bivariate and multi-variate analyses were performed to identify factors associated with having barriers to health care.

Results: Among 608 extracted cases, 164 (27.5\%) cases were advised to visit a medical facility, and 72 (11.8\%) were referred to a medical facility during the consultations. Those who were not covered by public insurance showed a 1.56-time (95\% confidence interval [Cl]: 1.19-2.05) higher prevalence of being advised to visit a medical facility when compared to those who were covered by public insurance. Unemployed people and students were more likely to be referred to a medical facility than were professional workers; the prevalence ratios were 3.28 (95\% Cl: 1.64-6.57) and 2.77 (95\% Cl: 1.18-6.46), respectively.

Conclusions: Although the majority were insured, almost 30\% were advised to visit a medical facility, which implied that they had had limited access to the formal health-care system before availing of the free consultations. The findings highlight those uninsured, unemployed people and students, who are considered vulnerable to access to health care. It is vital to provide those who are vulnerable with the necessary support while updatinge evidence, so that no one is "left behind."
\end{abstract}

Keywords: Migrants, Access to health care, Universal health coverage, Japan, Non-governmental organization

\footnotetext{
* Correspondence: michiyoh@med.nagoya-cu.ac.jp

'Department of Global and Community Health, Nagoya City University

School of Nursing, 1 Kawasumi, Mizuho-cho, Mizuho-ku, Nagoya 467-8601,

Japan

Full list of author information is available at the end of the article
}

(c) The Author(s). 2021 Open Access This article is licensed under a Creative Commons Attribution 4.0 International License, which permits use, sharing, adaptation, distribution and reproduction in any medium or format, as long as you give appropriate credit to the original author(s) and the source, provide a link to the Creative Commons licence, and indicate if changes were made. The images or other third party material in this article are included in the article's Creative Commons licence, unless indicated otherwise in a credit line to the material. If material is not included in the article's Creative Commons licence and your intended use is not permitted by statutory regulation or exceeds the permitted use, you will need to obtain permission directly from the copyright holder. To view a copy of this licence, visit http://creativecommons.org/licenses/by/4.0/ The Creative Commons Public Domain Dedication waiver (http://creativecommons.org/publicdomain/zero/1.0/) applies to the data made available in this article, unless otherwise stated in a credit line to the data. 


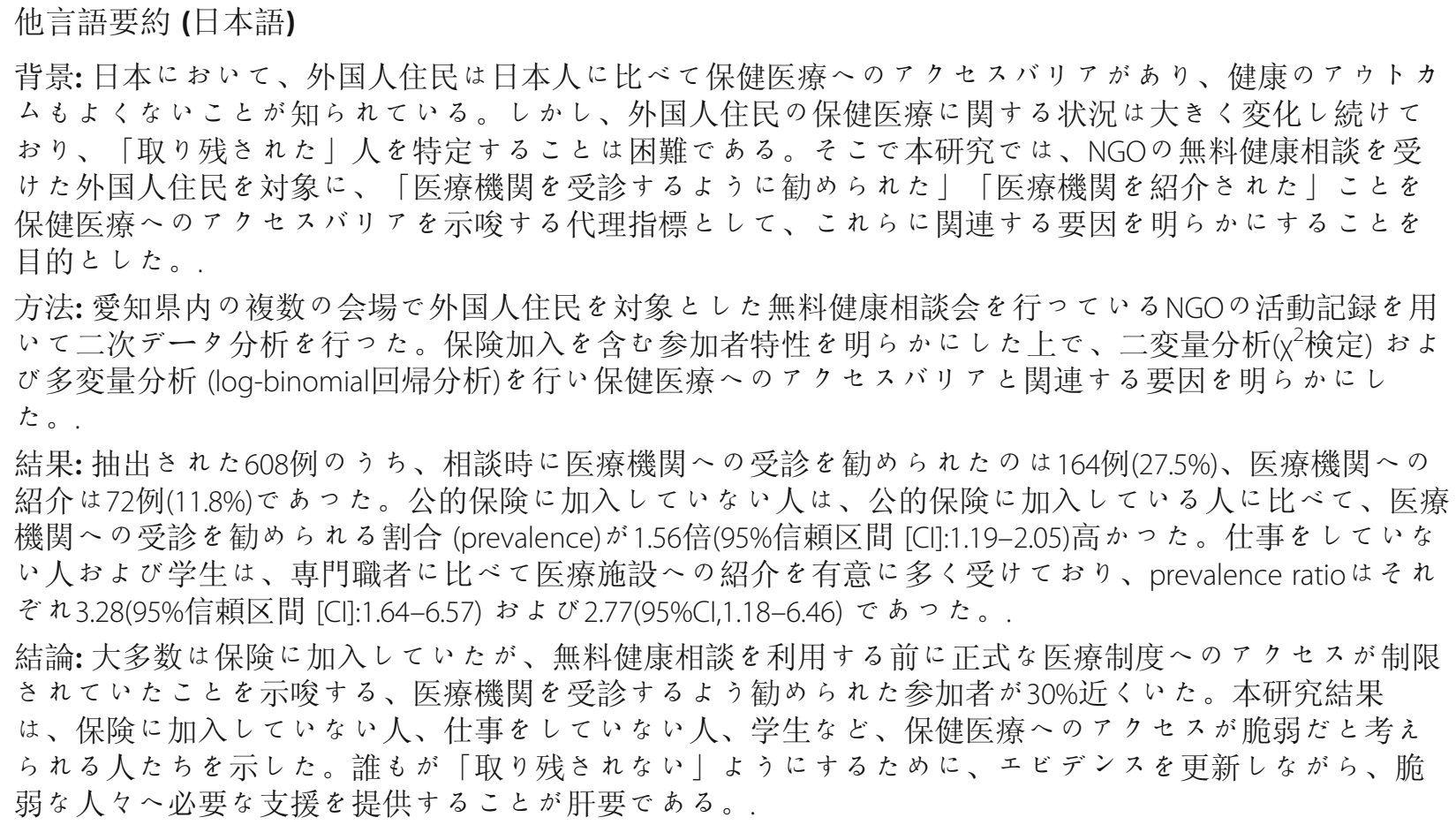

\section{Background}

"Leave no one behind," which represents the goal of eradicating poverty, discrimination, and exclusion and of reducing inequalities and vulnerabilities, is a core element of the global community's agenda [1]. To help realize this vision, universal health coverage (UHC) has been included as a target of the United Nation's Sustainable Development Goals, and achieving UHC has become a priority in the health sectors of many countries [2]. In this global context, Japan is recognized as a country where universal public insurance coverage was implemented in the country almost 60 years ago [3]. However, despite this long-term existence of the universal health insurance systemin Japan, a health gap exists, with some population groups having little access to coverage [4]. In particular, migrants and immigrants are considered to be vulnerable groups in regard to both access to health care and overall health [5-8].

Up to March 2019, Japan maintained a strict policy regarding foreign workers, except those who held visas based on their civil status (this is officially termed "based on status or position") and or those engaged in professional work or designated activities. Approximately 40 years ago, few foreign residents lived in Japan with the exception of "special permanent residents"; these were individuals (and their descendants) who stayed in Japan after losing their Japanese nationality when the Treaty of San Francisco took effect. Since the 1980s, however, the number of "newcomers" has been increasing, mainly as a result of various socio-economic circumstances, such as a shortage of labor in Japan and the country's buoyant economy [9, 10]. In 1990, the Japanese government adopted a new policy regarding immigrants with Japanese heritage, enabling them and their families to obtain residence status [11-13]. In 1993, a new residential qualification, "technical intern," was established. Technical interns are not officially laborers; however, they comprise part of the workforce in Japan [12, 14]. Another surge of newcomers has been the "students" who came to Japan as a result of the government's " 300,000 International Students Plan," which was introduced in $2008[15,16]$. In 1990, the total number of foreign residents in Japan exceeded one million, and 15 years later it reached two million [17]. By the end of 2019, foreign residents numbered 2,933,137 [18], representing $2.3 \%$ of the total population in Japan. "Newcomers" have outnumbered special permanent residents since the early 1990s [19]. Among all foreign residents, "general permanent residents" (permanent residents other than special permanent residents) are now the most prevalent group (27.0\%), followed by "technical interns" (14.0\%), and "students" (11.8\%) [18].

According to the latest "basic survey on wage structure" by the Ministry of Health, Labor and Welfare, Japan [20], the average monthly wage among foreign laborers was 223 thousand JPY whereas the total average was 308 thousand JPY. The duration of employment of the survey populations was different from each other 
(3.1 years whereas 12.4 years, respectively); however, compared with the average wage among the whole laborers in the age stratum of 30-35 years old, the average age of foreign laborers (33.4 years old in average) was still lower. Also, foreign laborers' wages varied much among resident status. Workers with status/positionbased visa (permanent residents, long-term residents and spouses or children of Japanese nationals or permanent residents) earned lower than professional and technical workers. The technical interns' average wage was less than a half of one of the professional and technical workers.

Japanese society must now respond to this rapid increase in the total number as well as diversity of foreign residents to ensure that people can coexist in the country [21]. In this regard, maintaining the their health is one of the most urgent social issues. Therefore, it is needed to understand access to health care among foreign residents and its associated factors. A study on access to health care among Nepalese migrants in 10 prefectures of Japan used two indicators; perceived better access to a doctor/health worker and needed to see a doctor/health worker, but did not. No need of Japanese interpreter during visit to health facilities and payment of the health insurance premium regularly were positively associated with both indicators. The length of stay in Japan and self-rated health were also positively associated with perceived better access [8]. Our team's previous study applied "no regular doctor" and "unmet health care needs" as negative access indicators and surveyed Filipino women in Aichi prefecture. In the study, emotional/ informational social support was associated with both indicators. Tangible social support, having a Japanese husband, and Japanese language proficiency were also associated with no regular doctor [22]. Some previous studies investigated factors associated with access to health-related resourses among specific groups but not directly focused on access to health care; for example, access to HIV testing among international students in Japanese language schools in Tokyo and access to health insurance among Latin American immigrants in a city [7, 23]. In Japan, there are few studies on access to health care among foreign residents. To our best knowledge, there is no quality study on access to health care among foreign residents in general in Japan.

In addition to the formal arrangements made by local governments, non-governmental organizations (NGOs) and non-profit organizations (NPOs; hereafter simply referred to as "NGOs") provide support for foreigners' health. Some of these NGOs provide informal, free medical check-ups and consultations. These NGO-organized free check-ups/consultations (hereafter referred to as "free consultations") are external to the formal health system in Japan $[24,25]$. The free consultations are not usually held in medical facilities (instead, public buildings such as community centers, schools, and churches are used); this means that the volunteer doctors who participate in these consultations do not have access to the appropriate equipment to provide full services for attendees. These NGOs visit various locations in their areas, typically visiting each place once or twice a year, and offer simple examinations and advice. During the free consultations, some attendees are advised to visit a medical facility that is part of the formal health system in order to undergo further examination and/or receive treatment. As people with no barriers to obtaining health care through the formal health system would be likely to visit official medical facilities rather than wait for a free consultation, it can be assumed that attending free consultations and being referred to a medical facility indicates that the attendee faced a barrier to visit a medical facility until they had the opportunity to attend the free consultation.

In the present study, using a dataset from an NGO that provides free medical check-ups in Aichi Prefecture (which has the second-largest foreign population in Japan [18], we aimed to identify, among foreign residents who attended free consultations, factors associated with "being advised to visit a medical facility" and "being referred to a medical facility"; these were considered to represent negative indicators of access to health care. Major characteristics of the Japanese health care system are universal health insurance and free access [26]. Anyone who stays in Japan for over three months should be covered by a public health insurance scheme [27] and can access any medical facility in the formal health care system [26]. Therefore, it is reasonable to assume that there is a barrier to health care in daily life if somebody, regardless of Japanese nationals or not, consults informal health services and holds a health problem which requires to visit the formal health care system at the point of an informal consultation. Replies from referral facilities were also reviewed to determine whether participants, after their referral, had entered the formal health care system. As studies on access to health-care among foreign residents in Japan remain limited, the current study will provide knowledge regarding the individuals who are actually "left behind," as well as information about the support such people require.

\section{Methods Study design}

Secondary data analyses were conducted using the activity records of an NGO located in Aichi Prefecture, Japan. 


\section{Data source}

The NGO, Medical Information Center, Aichi (MICA), has provided foreign residents with medical information and free monthly consultations since 1998 . Supported by volunteer doctors, dentists, and nurses, as well as nonmedical volunteers, the free consultations are provided in various locations in Aichi Prefecture, with each location being visited in rotation. The documentation for these consultation activities comprises a four-page form that the MICA staff members and volunteers complete for each attendee. The pages cover: 1) personal information, including sex, age, date of birth, nationality, occupation, years living in Japan, whether the attendee is covered under a Japanese public insurance scheme, medical history, family medical history, complaints and symptoms; 2) lifestyle, 3) data obtained through physical check-ups (height, weight, blood pressure, pulse rate, body temperature, and urine analysis results) and the results of the consultation with the doctor, including an overall assessment (i.e., the actions the attendee should take); and 4) oral check-ups and the results of consultations with a dentist, with an overall assessment (the actions the attendee should take). The form is available in 10 different languages (English, Portuguese, Spanish, Chinese, Korean, Vietnamese, Filipino, Indonesian, Burmese, and Thai), which ensures that most attendees can understand the questions. All of the information gathered on these forms is entered into a datamanagement program by MCIA staff members.

\section{Participants}

For the present study, anonymous data of all adults (aged 18 years or older) who participated in the free monthly consultation activities between 2012 and 2016 were extracted from the full dataset; this was performed under the terms of a data-use agreement between the first author and the NGO (MICA). We used 2012 as the start date for the data extraction because in 2012 the Japanese government made a legislative change that allowed foreign residents who lived in Japan for over three months to apply for National Health Insurance (previously, only foreign residents who had lived in Japan for over one year were eligible.) Cases were excluded if the age was unknown (four cases), nationality was Japanese (16 cases), the participant was a traveler (three cases), and if all records except attributes were missing (one case). Thus, of a total of 632 cases, 608 were used for the analyses.

\section{Access to health care framework}

There are various models and frameworks to consider access to health care [28-30]. For example, the model published by the Institute of Medicine in the United States [31] applies "use" of services as the intermediate indicators of its access to health care model. Andersen and colleagues [32, 33] have developed several frameworks over the years. In their frameworks, both individual characteristics and contextual characteristics influence health care access. Penchansky and Thomas [34] defined access as entry into or use of the health care systems and suggested specific dimensions, such as availability, accessibility, accommodation, affordability and acceptability, to describe the "fit" between the patient and health care system. Levesque et al. [30] suggested access as "opportunity" based on the review of previous studies. International surveys often use a question asking "unmet health care needs" [35], which are also often used in studies on nationals and migrants in Japan [22, $23,36]$.

\section{Variables measurement \\ Explanatory variables}

All available participant characteristics included in the dataset, such as sex, age group, region of origin, occupation, whether he/she was covered by a Japanese public insurance scheme, and time living in Japan, were used as explanatory variables. Supply-side variables were not included in the dataset we used. Therefore, only attendee (demand-side) variables were included as explanatory variables in our analysis model.

Region of origin was defined based on the nationality recorded on the form and categorized based on UnitedNations-recognized regions, unless the nationality was Brazilian, Chinese, Filipino, Vietnamese, or a highincome country that is defined by the World Bank. As Brazilian, Chinese, Filipino, and Vietnamese were the four major groups, they were treated as a single category. "Other Asia" featured 68 participants from South Asia (five countries), 34 from South-East Asia, except Vietnam and the Philippines, (three countries), two from West Asia (one country), and one from Central Asia (one country). Participants included in the "other" region were as follows: 35 from Latin America, except Brazil, (five countries), six from East Africa, three from West Africa, three from North Africa, one from Central Africa, two from Russia, and one from Melanesia.

In the data-collection form, attendee's occupation was determined using an open-ended, self-reported answer and, for the present study, we developed occupational categories based on these answers. If the type of factory work or construction work was recorded, or if the occupation was simply recorded as "factory," the participant was categorized as engaging in "factory or construction work." If part-time or contingent work (Arubaito, Paato, or Haken, in Japanese) was recorded as an occupation, the participant was categorized as having a "non-regular job." "Trainee" and "intern" were combined to form "trainee/intern." These three categories were then 
further grouped into the category "labor and nonregular," because they often overlap and are used interchangeably in daily conversation. Professional workers, such as teachers, engineers, and company workers, were also combined because they are considered to represent the formal sector. Housewives and the unemployed were combined because these people usually stay home and, again, these terms are sometimes used interchangeably in daily conversation. "Other" included nine people engaged in "service," seven helpers (care assistants), four people engaged in religion-related work, three salespeople, three businesspeople, three cooks, two refugees, two volunteers, one babysitter, and one diplomat. Two occupation records could not be categorized, and were also included in "other."

\section{Outcome variables}

All cases for which there were any records on the third page of the form were defined as "had a medical consultation." Two items were used as the outcome variables and considered as indicators of having barriers to health care: 1) "being advised to visit a medical facility" (attributed if the participant was advised to visit a medical facility); and 2) "being referred to a medical facility" (attributed if the participant was referred to a medical facility, with or without a referral letter). We assumed that participants who were advised or referred did not have easy access to the formal health-care system before attending the NGO's consultations. Participants identified as 2) were part of 1), but were considered more serious cases.

\section{Data analysis}

First, participant characteristics (sex, age group, region of origin, occupation, whether he/she was covered by a Japanese public insurance scheme, and time living in Japan) were described. The frequency and the percentage of each category were calculated. Second, the two indicators of barriers to health care ("being advised to visit a medical facility" and "being referred to a medical facility") were analyzed in terms of participant characteristics using chi-square tests. Third, log-binomial regression analyses were performed to calculate the prevalence ratios (PRs) of "being advised to visit a medical facility" and "being referred to a medical facility" for each participant characteristic. Variables that showed, in the chisquare tests, statistical associations for each of the two access indicators were included in the model. Furthermore, if the participants were referred to a medical facility with or without a referral letter, the recorded consequences were described. Stata SE version 12.1 (Stata Corp) was used for all statistical analyses.

\section{Results}

\section{Participant characteristics}

One-third (34.0\%) of the participants were under 30 years of age. Two-thirds of the cases (67.8\%) were Vietnamese, Filipino, Brazilian, or Chinese. Almost 30\% did not report their jobs. The second-largest occupation group was laborers and non-regular workers (25.0\%), followed by professional/company workers $(24.3 \%$; the majority of whom were teachers, engineers, and translators). Over one-third (34.7\%) had lived in Japan for five years or longer, and almost one-quarter (24.5\%) for ten years or longer (Table 1$)$.

\section{Associations between access to health care and participant characteristics}

Of the 596 participants who had received medical consultations, $164(27.5 \%)$ were advised to visit a medical facility. Occupation category and insurance coverage were associated with being advised to visit a medical facility $(p=0.01$ and $p<0.01$, respectively; Table 2$)$. Meanwhile, $72(11.8 \%)$ cases were referred to a medical facility, and the occupation category also showed a statistical association with referral $(p<0.01$; Table 3$)$.

\section{Multiple regression analysis of access to health care}

Log-binomial regression analyses suggested that unemployed people, including housewives, showed a higher PR of being advised to visit a medical facility than professional/company workers; the adjusted PR was 2.08 (95\% confidence interval [CI]: 1.40-3.11). Among those who were not covered by public insurance, the prevalence of being advised to visit a medical facility was 1.56 times as high as that for participants who were covered by public insurance (95\% CI: 1.18-2.05). Unemployed people and students, were more likely to be referred to a medical facility than were professional/company workers; the PRs were 2.77 (95\% CI: 1.64-6.57) and 3.28 (95\% CI: 1.18-6.46), respectively (Table 4).

\section{Consequences of the referrals}

Of the 72 people who were referred to a medical facility with or without a referral letter, 11 received replies from a medical doctor. In addition, medical information letters were sent from medical facilities to the NGO for two cases who were not recorded as "referred." The date of the medical visit was known for five of these cases; only one person visited a medical facility within a month of the free consultation. Of the 13 cases, no urgent and/ or serious disease was found; however, three people were diagnosed with valvular regurgitation, atrial fibrillation, or a thyroid tumor after further investigation, and were placed under medical observation. 
Table 1 Participants characteristics among foreign residents who participated in free consultation activities held in Aichi Prefecture from 2012 to $2016(N=608)$

\begin{tabular}{|c|c|c|}
\hline Characteristics & Frequency & $\%$ \\
\hline \multicolumn{3}{|l|}{ Sex } \\
\hline Female & 346 & 56.9 \\
\hline Male & 262 & 43.1 \\
\hline \multicolumn{3}{|l|}{ Age group } \\
\hline-29 years old & 207 & 34.1 \\
\hline 30-39years old & 176 & 29.0 \\
\hline 40-49 years old & 131 & 21.6 \\
\hline 50- years old & 94 & 15.5 \\
\hline \multicolumn{3}{|l|}{ Region of origin } \\
\hline Vietnam & 123 & 20.2 \\
\hline Philippines & 114 & 18.8 \\
\hline Brazil & 105 & 17.3 \\
\hline China & 70 & 11.5 \\
\hline Other Asia & 105 & 17.3 \\
\hline High-income country & 40 & 6.6 \\
\hline Other & 51 & 8.4 \\
\hline \multicolumn{3}{|l|}{ Occupation } \\
\hline Labour/non-regular ${ }^{\mathrm{a}}$ & 152 & 25.0 \\
\hline Professional/company & 148 & 14.3 \\
\hline Student & 31 & 5.1 \\
\hline Unemployed $^{\mathrm{b}}$ & 58 & 9.5 \\
\hline Other & 37 & 6.1 \\
\hline No answer & 182 & 29.9 \\
\hline \multicolumn{3}{|c|}{ Duration of living in Japan (years) } \\
\hline$<1$ year & 83 & 13.7 \\
\hline$\geqq 1$ year, $<5$ years & 222 & 36.5 \\
\hline$\geqq 5$ year & 211 & 34.7 \\
\hline Unknown & 92 & 15.1 \\
\hline \multicolumn{3}{|c|}{ Coverage of a Japanese public health insurance } \\
\hline Covered & 497 & 81.7 \\
\hline Not covered & 101 & 16.6 \\
\hline Unknown & 10 & 1.6 \\
\hline
\end{tabular}

ancluding trainees/interns

b Including housewives

\section{Discussion}

We conducted secondary analyses of data for a sample of diverse foreign residents who attended free medical consultations offered by an NGO in various locations in Aichi Prefecture. Four fifths of the participants were covered by Japanese public insurance; however, in the consultations with the volunteer doctors over one fourth of the participants were advised to visit a medical facility. It was assumed that these individuals generally experienced barriers to accessing the formal health-care system. Risk groups regarding being advised to visit a medical facility or being referred to a medical facility were found to be people who are uninsured, people who are unemployed, and students. Of the 72 cases who were referred to a medical facility, the NGO received reply letters from medical facilities for just 11 cases.

Insurance coverage was an associated factor with being advised to visit a medical facility, which was our hypothetical indicator of access to health care. The finding is consistent with a previous study of Nepalese migrants, although indicators are not the same. In the Nepali study, $35 \%$ of the participants had not paid the insurance premium for a year or more [8]. This figure is higher than the proportion of no coverage of a public health insurance scheme in our current study (19\%). Our team studied unmet health care needs among Filipino women, and the insurance coverage was not associated probably due to the high coverage (92\%) among the target group [22]. Japan implemented universal public insurance coverage in 1961 [3], and in 2012 implemented a law to allow every person living in Japan, regardless of their nationality (but excepting visitors staying for three months or shorter), to receive coverage under a Japanese public insurance scheme [27]. As there are numerous insurance schemes in Japan, it is difficult to obtain exact figures regarding coverage among foreign residents. According to reports from some local governments and NGOs, however, it has been estimated that approximately $80 \%$ of foreign residents are covered by a Japanese public insurance scheme [7,37]. This shows a dramatic improvement in coverage in recent decades, as in 2004 a survey conducted by a local government reported that this figure was $64.4 \%$ [38]. Our findings contribute to know that the low coverage rate among foreign residents in Japan, where there is a universal health insurance coverage policy, and to prove a social concern that no insurance coverage is a barrier to health care.

Previous studies on access to health care among Nepalese residents in Japan did not find associations between access variables and employment status [8]. In contrast, our study suggested that unemployed people represent a high-risk group. Although it is difficult to speculate the underlying reasons, income and social network, which was unknown in our dataset, may have an important effect. In addition, students were found to represent another possible risk group. In May 2019, 312, 214 foreign students were living in Japan [39]. Among these, 53.2\% were studying at professional training colleges, university preparatory courses, or Japanese language institutes [39]; institutions for which the School Health and Safety Act generally does not apply. According to a 2009 survey conducted by the Association for the Promotion of Japanese Language Education, 66.5\% 
Table 2 Whether advised to visit a medical facility according to participant characteristics among foreign residents who participated in free consultation activities held in Aichi Prefecture from 2012 to $2016\left(N=596^{a}\right)$

\begin{tabular}{|c|c|c|c|c|c|}
\hline \multirow[t]{3}{*}{ Characteristics } & \multicolumn{4}{|c|}{ Whether advised to visit a medical facility } & \multirow[t]{3}{*}{$p$-value ${ }^{b}$} \\
\hline & \multicolumn{2}{|c|}{ Yes $(N=164)$} & \multicolumn{2}{|c|}{ No $(N=432)$} & \\
\hline & $\mathrm{n}$ & $\%$ & $\mathrm{n}$ & $\%$ & \\
\hline \multicolumn{6}{|l|}{ Sex } \\
\hline Female & 100 & 29.7 & 237 & 70.3 & \multirow[t]{2}{*}{0.18} \\
\hline Male & 64 & 24.7 & 195 & 75.3 & \\
\hline \multicolumn{6}{|l|}{ Age group } \\
\hline-29 years old & 54 & 26.3 & 151 & 73.7 & \multirow[t]{4}{*}{0.36} \\
\hline 30-39years old & 41 & 23.8 & 131 & 76.2 & \\
\hline 40-49years old & 39 & 30.5 & 89 & 69.5 & \\
\hline 50- years old & 30 & 33.0 & 61 & 67.0 & \\
\hline \multicolumn{6}{|l|}{ Region of origin } \\
\hline Vietnam & 30 & 24.6 & 92 & 75.4 & \multirow[t]{7}{*}{0.59} \\
\hline Philippines & 37 & 33.3 & 74 & 66.7 & \\
\hline Brazil & 27 & 26.2 & 76 & 73.8 & \\
\hline China & 15 & 22.4 & 52 & 77.6 & \\
\hline Other Asia & 27 & 26.0 & 77 & 74.0 & \\
\hline High-income country & 14 & 35.0 & 26 & 65.0 & \\
\hline Other & 14 & 28.6 & 35 & 71.4 & \\
\hline \multicolumn{6}{|l|}{ Occupation } \\
\hline Labour/non-regular ${ }^{c}$ & 36 & 24.2 & 113 & 75.8 & \multirow[t]{6}{*}{0.01} \\
\hline Professional/company & 33 & 22.5 & 114 & 77.6 & \\
\hline Student & 9 & 29.0 & 22 & 71.0 & \\
\hline Unemployed $^{d}$ & 26 & 46.4 & 30 & 53.6 & \\
\hline Other & 14 & 37.8 & 23 & 62.2 & \\
\hline No answer & 46 & 26.1 & 130 & 73.9 & \\
\hline \multicolumn{6}{|c|}{ Coverage under Japanese public insurance ${ }^{e}$} \\
\hline Covered & 121 & 24.9 & 366 & 75.2 & \multirow[t]{2}{*}{$<0.01$} \\
\hline Not covered & 41 & 41.0 & 59 & 59.0 & \\
\hline \multicolumn{6}{|l|}{ Duration of living in Japan ${ }^{f}$} \\
\hline$<1$ year & 23 & 27.7 & 60 & 72.3 & \multirow[t]{3}{*}{0.90} \\
\hline$\geqq 1$ year, $<5$ years & 59 & 26.7 & 162 & 73.3 & \\
\hline$\geqq 5$ years & 59 & 28.6 & 147 & 71.4 & \\
\hline
\end{tabular}

${ }^{a}$ Twelve participants were excluded because it was not known if they had been advised to visit a medical facility

${ }^{\mathrm{b}}$ Chi-square test

Including trainees/interns

dincluding housewives

eUnknown for 9 participants

fUnknown for 86 participants

of the respondents from Japanese language schools had experienced illness or injury since arriving in Japan; of these, $2.3 \%$ had been hospitalized, $39.8 \%$ had visited medical facilities, and $2.7 \%$ had consulted their school's medical personnel [25]. Further, among this group the most frequent answer to a question regarding the types of treatment used was "self-medication" (44.3\%) [40]. Meanwhile, in a survey of students in Japanese language schools in Tokyo, $48.7 \%$ of the surveyed students reported that they did not think they had access to doctors/health workers [23]. Foreign students in Japanese language schools have become a target population in regard to measures to address tuberculosis [41], with foreign-born people accounting for a major part of new cases among young generations [42]. The government's "300,000 International Students Plan," has led to the 
Table 3 Whether referred to a medical facility according to participant characteristics among foreign residents who participated in free consultation activities held in Aichi Prefecture from 2012 to $2016\left(N=596^{\mathrm{a}}\right)$

\begin{tabular}{|c|c|c|c|c|c|}
\hline \multirow[t]{3}{*}{ Characteristics } & \multicolumn{4}{|c|}{ Whether referred to a medical facility } & \multirow[t]{3}{*}{$p$-value ${ }^{b}$} \\
\hline & \multicolumn{2}{|c|}{ Yes $(N=72)$} & \multicolumn{2}{|c|}{ No $(N=524)$} & \\
\hline & $\bar{n}$ & $\%$ & $\mathrm{n}$ & $\%$ & \\
\hline \multicolumn{6}{|l|}{ Sex } \\
\hline Female & 45 & 13.4 & 292 & 86.6 & \multirow[t]{2}{*}{0.28} \\
\hline Male & 27 & 10.4 & 232 & 89.6 & \\
\hline \multicolumn{6}{|l|}{ Age group } \\
\hline-29 years old & 25 & 12.2 & 180 & 87.8 & \multirow[t]{4}{*}{0.98} \\
\hline 30-39 years old & 22 & 12.8 & 150 & 87.2 & \\
\hline 40-49 years old & 15 & 11.7 & 113 & 88.3 & \\
\hline 50- years old & 10 & 11.0 & 81 & 89.0 & \\
\hline \multicolumn{6}{|l|}{ Region of origin } \\
\hline Vietnam & 17 & 13.9 & 105 & 86.1 & \multirow[t]{7}{*}{0.25} \\
\hline Philippines & 14 & 12.6 & 97 & 87.4 & \\
\hline Brazil & 7 & 6.8 & 96 & 93.2 & \\
\hline China & 6 & 9.0 & 61 & 91.0 & \\
\hline Other Asia & 19 & 18.3 & 85 & 81.7 & \\
\hline High-income country & 4 & 10.0 & 36 & 90.0 & \\
\hline Other & 5 & 10.2 & 44 & 89.8 & \\
\hline \multicolumn{6}{|l|}{ Occupation } \\
\hline Labour/non-regular ${ }^{c}$ & 15 & 10.1 & 134 & 89.9 & \multirow[t]{6}{*}{$<0.01$} \\
\hline Professional/company & 12 & 8.2 & 135 & 91.8 & \\
\hline Student & 7 & 22.6 & 24 & 77.4 & \\
\hline Unemployed $^{d}$ & 15 & 26.8 & 41 & 73.2 & \\
\hline Other & 4 & 10.8 & 33 & 89.2 & \\
\hline No answer & 19 & 10.8 & 157 & 89.2 & \\
\hline \multicolumn{6}{|c|}{ Coverage under Japanese public insurance ${ }^{e}$} \\
\hline Covered & 57 & 11.7 & 430 & 88.3 & \multirow[t]{2}{*}{0.52} \\
\hline Not covered & 14 & 14.0 & 86 & 86.0 & \\
\hline \multicolumn{6}{|l|}{ Duration of living in Japan ${ }^{f}$} \\
\hline$<1$ year & 10 & 12.0 & 73 & 88.0 & \multirow[t]{3}{*}{0.75} \\
\hline$\geqq 1$ year, $<5$ years & 30 & 13.6 & 191 & 86.4 & \\
\hline$\geqq 5$ years & 23 & 11.2 & 183 & 88.8 & \\
\hline
\end{tabular}

${ }^{a}$ Twelve participants were excluded because it was not known if they had been referred to a medical facility

${ }^{\mathrm{b}} \mathrm{Chi}$-square test

Including trainees/interns

dincluding housewives

eUnknown for 9 participants

fUnknown for 86 participants

arrival in Japan of a cohort of foreign students with diverse characteristics. A survey conducted by a governmental organization suggested that over three-quarters of privately-funded foreign students hold part-time jobs, among which almost $70 \%$ work over $15 \mathrm{~h}$ per week [43]; working such relatively long hours while also attempting to fulfill education responsibilities might explain the health-care-related vulnerability among this group.
Systems to accept foreign students should be improved. Japanese society needs to recognize the vulnerability of this group.

Another important finding was that, after volunteer doctors sent attendees to health-care providers in the formal health care system, few replies were obtained. There are at least two possible explanations for this. First, the patients may not have visited a medical facility 
Table 4 Multiple regression analysis of "being advised to visit a medical facility" and "being referred to a medical facility" among foreign residents who participated in free consultation activities held in Aichi Prefecture from 2012 to 2016

\begin{tabular}{|c|c|c|c|}
\hline & \multicolumn{2}{|c|}{ Being advised to visit a medical facility $\left(N=587^{\mathrm{a}}\right)$} & \multirow[t]{2}{*}{$p$-value } \\
\hline & $a P R^{b}$ & $95 \% \mathrm{Cl}$ & \\
\hline \multicolumn{4}{|l|}{ Occupation } \\
\hline Professional/company & \multicolumn{3}{|c|}{ reference } \\
\hline Labour/non-regular ${ }^{c}$ & 1.06 & $0.70-1.60$ & 0.79 \\
\hline Student & 1.28 & $0.69-2.37$ & 0.44 \\
\hline Unemployed $^{d}$ & 2.08 & $1.40-3.11$ & $<0.01$ \\
\hline Other & 1.47 & $0.87-2.49$ & 0.15 \\
\hline No answer & 1.17 & $0.79-1.72$ & 0.43 \\
\hline \multicolumn{4}{|c|}{ Coverage under Japanese public insurance } \\
\hline Covered & \multicolumn{3}{|c|}{ reference } \\
\hline \multirow[t]{3}{*}{ Not covered } & 1.56 & $1.19-2.05$ & $<0.01$ \\
\hline & \multicolumn{2}{|c|}{ Being referred to a medical facility $\left(N=596^{\mathrm{e}}\right)$} & $p$-value \\
\hline & $P R$ & $95 \% \mathrm{Cl}$ & \\
\hline \multicolumn{4}{|l|}{ Occupation } \\
\hline Professional/company & \multicolumn{3}{|l|}{ ref } \\
\hline Labour/non-regular ${ }^{c}$ & 1.23 & $0.60-2.54$ & 0.57 \\
\hline Student & 2.77 & $1.18-6.46$ & 0.02 \\
\hline Unemployed $^{d}$ & 3.28 & $1.64-6.57$ & $<0.01$ \\
\hline Other & 1.32 & $0.45-3.87$ & 0.61 \\
\hline No answer & 1.32 & $0.66-2.63$ & 0.43 \\
\hline
\end{tabular}

$P R$ prevalence ratio, $a P R$ adjusted prevalence ratio

95\% Cl 95\% confident interval

${ }^{a}$ Twenty-one participants were excluded because it was not known if a) they were covered by Japanese public insurance or b) if they had been advised to visit a medical facilitys

${ }^{\mathrm{b}}$ Mutually adjusted

Including trainees/interns

dincluding housewives

'Twelve participants were excluded because whether they had been referred to a medical facility was unknown

as advised; and second, the doctors who received the patients did not issue medical information letters to the NGO. Among the returned letters, we found that some patients had been placed under observation. If these referred patients had not visited a medical facility within an appropriate time, their diagnosis would have been delayed. Practically, it is difficult to track referred patient and to check whether they contacted the formal healthcare system. Under the government plan for "Promotion of Multicultural Coexistence," various NGOs, along with local governments, are expected to take a role in addressing livability issues for foreign residents [44]. To ensure access to health-care among foreign residents, better communication between NGOs and the formal health care system is required.

We applied the concept of "unmet health care needs" [35]. However, due to the nature of secondary data, information available in the dataset might not have been the most ideal. Globally standardized questions were not asked. After careful observation, we assumed that participants being advised to visit a medical facility and being referred to a medical facility indicated underuse of the formal health care system, and decided to apply this as negative indicators of access to health care in limited information. Both supply-side and demand-side characteristics are considered associated with access to health care in theories and frameworks of access to health care. We could not include supply-side variables in our model because such information was not available in our dataset. Although the availability of specific supports, for example, translators, might be an issue, considering the Japanese health care system and the density of health facilities, health-care providers' physical availability in urban areas does not matter much. Therefore, even supply-side variables were unavailable, we believe that our analyses were valid.

Cases in the dataset were not randomly sampled from all foreign residents in Aichi Prefecture. Although the free consultations are open to everybody, people with similar attributes might have attended as a group. Consequently, the participant characteristics determined in this research may have been biased. However, compared 
with the proportions of countries of origin listed for residents of Aichi Prefecture in the government statistics for the corresponding years [45], our data can be considered to better reflect the target population in the prefecture. A venue-based approach for sampling hard-to-reach populations would be an acceptable method of obtaining more accurate data $[46,47]$. It was reported that using only census and vital statistics may not be suitable for capturing the reality of the health situations among foreign residents [48]. Official data describing access to health care among foreign people remain limited; for example, to the best of our knowledge there are no official data regarding the prevalence of uninsured foreign residents. As previous studies have suggested [7, 23, 49], migrants are likely to be mobile, meaning it may be difficult to study foreign residents through mail surveys with random sampling. A limited number of studies have been published regarding access to health care among foreign residents in Japan. One recent study employed purposive sampling at restaurants to sample Nepalese participants [8]. Another study, which was not directly studied access to health care, sought to use random sampling, but only targeted Latin Americans in one city [7]. Thus, analysis of alternative data, such as that used in our study, is needed. Although the information we used was not collected for research purposes, our findings are nevertheless informative. As we have shown, analyzing data from NGOs can strengthen understanding of, and foster improvement in, access to health care and health outcomes. In the future, studies with randomly selected data, obtained through collaboration with local governments, will be required for more rigorous analyses.

There were some other limitations to this study. First, the data were entered by case (consultation), not by person. If the dataset includes many people who attended multiple consultations, the statistical findings may have been overestimated. However, because free consultations are held in different places in Aichi Prefecture over the course of the year, it is unlikely that the number of repeat visitors within one year would be large. Second, obtaining reliable answers to some questions from some participants was difficult. For example, occupation was an open-ended, self-report answer, and volunteers (interviewers) sometimes needed to infer attendees' jobs from their responses. As a result, the occupations of nearly $30 \%$ of the participants were unknown and were masked in the category of "No answer", which may have influenced analyses.

Among possible risk groups we found regarding access to health care, those uninsured and the unemployed are considered hard-to-reach groups. It is considered that collaboration with NGOs, which is suggested by the government, should be essential to support these groups.
Students were found another vulnerable group although they are insured by regulations. Japanese society needs to recognize the vulnerability of this group. Also, systems to accept international students should be improved. The current study was realized by analyzing NGO's data, and such collaboration is necessary to generate evidence to support foreign residents in Japan.

\section{Conclusion}

Secondary analysis of NGO's activity records revealed the diversity of foreign residents living in Aichi Prefecture who require informal, free health consultations. Although the majority of the participants were covered by Japanese health insurance, almost 30\% were advised to visit a medical facility, which implied that they had limited access to the formal health-care system before availing of the NGO's consultations. Being advised to visit a medical facility was associated with insurance coverage. In addition to unemployed people, students were found to be a risk group. We found that not only assumed hard-to-reach groups, such as those uninsured and unemployed, but also those who are systematically accepted in the country, such as students, were considered likely to have a barrier to health care. Japanese society, including NGOs, should improve systems to accept them and also generate updated evidence about who is "left behind."

\section{Abbreviations \\ Cl: Confidence interval; MICA: Medical Information Center, Aichi; NGO: Non- governmental organization; NPO: Non-profit organization; PR: Prevalence ratio; UHC: Universal health coverage}

\section{Acknowledgements}

We are grateful to the Medical Information Center, Aichi (MICA), which gave us the opportunity to analyse valuable data. In particular, we would like to acknowledge the work of Ms. Norimi Fujita and Ms. Michiko Okihashi, MICA office staff members, who have been organizing free monthly consultation activities and managing participant data. We sincerely appreciate the efforts of all the volunteers who have been supporting MICA activities.

\section{Authors' contributions}

$\mathrm{MH}$ designed the study, EM and $\mathrm{MH}$ cleaned the dataset and $\mathrm{MH}, \mathrm{EM}$ and AY analysed data. MH and EM drafted the manuscript. All authors contributed to the writing of the manuscript and approved the final draft.

\section{Funding}

This study was funded by Grant-in-Aid for Research in Nagoya City University for Fiscal 2018 (Category 3, Number 15).

\section{Availability of data and materials}

The datasets generated and/or analyzed during the current study are not publicly available due to agreement between the data owner (MICA) and the first author but are available from the first author on reasonable request.

\section{Declarations}

Ethics approval and consent to participate

This study was approved by the ethical committee of the Nagoya City University School of Nursing, Japan (ID: 17009-2) and by a board meeting of MICA on June 10, 2017. Extracted data were anonymous and no researcher knew the names of participants. Based on the agreement between MICA 
and the first author only researchers approved by the MICA board meeting could access the dataset.

\section{Consent for publication}

Not applicable.

\section{Competing interests}

\section{None declared.}

\section{Author details}

'Department of Global and Community Health, Nagoya City University School of Nursing, 1 Kawasumi, Mizuho-cho, Mizuho-ku, Nagoya 467-8601, Japan. ${ }^{2}$ Nagoya City University Hospital, 1 Kawasumi, Mizuho-cho, Mizuho-ku, Nagoya 467-8601, Japan.

\section{Received: 11 December 2020 Accepted: 29 April 2021}

\section{Published online: 10 June 2021}

\section{References}

1. United Nations. Resolution adopted by the general assembly on 25 September 2015: Transformaing our world: the 2030 agenda for sustainable development (a/RES/70/1). New York: United Nations; 2015. Available from: https://undocs.org/A/RES/70/1. Cited 9 Dec 2020

2. Kieny MP, Bekedam H, Dovlo D, Fitzgerald J, Habicht J, Harrison G, et al. Strengthening health systems for universal health coverage and sustainable development. Bull World Health Organ. 2017;95(7):537-9. https://doi.org/1 0.2471/BLT.16.187476.

3. Ikegami N, Yoo BK, Hashimoto H, Matsumoto M, Ogata H, Babazono A, et al. Japanese universal health coverage: evolution, achievements, and challenges. Lancet (London, England). 2011;378(9796):1106-15.

4. Watanabe $\mathrm{R}$, Hashimoto $\mathrm{H}$. Horizontal inequity in healthcare access under the universal coverage in Japan; 1986-2007. Soc Sci Med. 2012;75(8):1372-8. https://doi.org/10.1016/j.socscimed.2012.06.006.

5. Yamamura J, Sawada T. A study on patients with tuberculosis among foreigners overstayed in Japan after expiration of visa--activities over three years [in Japanese]. Kekkaku : [Tuberculosis]. 2002;77(10):671-7.

6. Komatsu $\mathrm{R}$, Sawada T. The role of international migration in infectious diseases: the HIV epidemic and its trends in Japan. Int J Health Serv Plann Adm Eval. 2007;37(4):745-59. https://doi.org/10.2190/HS.37.4.j.

7. Suguimoto SP, Ono-Kihara M, Feldman MD, Kihara M. Latin American immigrants have limited access to health insurance in Japan: a cross sectional study. BMC Public Health. 2012;12(1):238. https://doi.org/10.11 86/1471-2458-12-238.

8. Shakya P, Tanaka M, Shibanuma A, Jimba M. Nepalese migrants in Japan: what is holding them back in getting access to healthcare? PLoS One. 2018; 13(9):e0203645. https://doi.org/10.1371/journal.pone.0203645.

9. Kondo A. Migration and law in Japan. Asia Pac Policy Stud. 2015;2(1):155-68. https://doi.org/10.1002/app5.67.

10. Nagayama T. Foreign workers recruiting policies in Japan. Asian Pac Migr J. 1996:5(2-3):241-64. https://doi.org/10.1177/011719689600500205.

11. Mori H. Foreign migrant workers in Japan: trends and policies. Asian Pac Migr J. 1995;4(2-3):411-27. https://doi.org/10.1177/011719689500400212

12. Kuwahara Y. Migrant workers in the post-war history of Japan. Jpn Labor Rev. 2005;2(4):25-47

13. Tezuka K. Foreign workers in Japan: reality and challanges. Jpn Labor Rev. 2005;2(4):48-71.

14. Tian Y. Workers by any other name: comparing co-ethnics and 'interns' as labour migrants to Japan. J Ethn Migr Stud. 2019;45(9):1496-514. https://doi. org/10.1080/1369183X.2018.1466696.

15. Student Exchange Office, Student Services Division, Higher Education Bureau. Outline of the student exchange system: study in Japan and abroad. Tokyo: Ministry of Education, Culture, Sports, Science and Technology, Japan; 2008. Available from: http://www.mext.go.jp/a_menu/ koutou/ryugaku/081210/001.pdf. Cited 9 Dec 2020

16. Ministry of Foreign Affairs, Japan. Student exchange programs: Ministry of Foreign Affairs, Japan; 2019. Available from: https://www.mofa.go.jp/policy/ culture/people/student/index.html. Cited 9 Dec 2020

17. Immigration Services Agency of Japan. Initiatives to accept new foreign nationals and for the realization of society of harmonious coexistence. Tokyo: Ministry of Justice, Japan; 2020. Available from: http://www.moj.go. jp/content/001308076.pdf. Cited 9 Dec 2020
18. Immigration Services Agency of Japan. Reiwa-gan-nen matsu genzai ni okeru zairyugaikokujnsu ni tsuite [in Japanese] (The number of foreign residents as of the end of 2019): Ministry of Justice, Japan; 2020. Available from: http://101.110.15.201/isa/publications/press/nyuukokukanri04_00003. html. Cited 9 Dec 2020

19. "Sentakusuru Mirai" linkai (Comittee on "Choosing the future"). Jinko wo meguru genjo to kadai [in Japanese] (Current status and issues regarding population). Sentakusuru mirai - Jinkosuikei kara mietekuru miraizo(Choosing the future - The future as seen from population estimates). Tokyo: Cabinet Office, Japan; 2015. 67-109. Available from: https://www5.ca o.go.jp/keizai-shimon/kaigi/special/future/sentaku/pdf/all_03.pdf. Cited 9 Dec 2020

20. Ministry of Health Labour and Welfare. Reiwa-gan-nen chingin kouzou kihon toukei chousa [in Japanese] (Basic survey on wage structure). Tokyo: Ministry of Health, Labour and Welfare; 2019. Available from: https://www. mhlw.go.jp/toukei/itiran/roudou/chingin/kouzou/z2019/index.html. Cited 31 March 2021

21. Director of the International Affairs Office, Local Administration Bureau, Ministry of Internal Affairs and Communications Japan. Chiiki ni okeru tabunkakyosei suishin puran no kaitei ni tsuite [in Japanese] (About revisions of multi-cultural coexistance plans in the community). Tokyo: Ministry of Internal Affairs and Communications, Japan; 2020. Available from: https://www.soumu.go.jp/main_content/000718717.pdf. Cited 9 Dec 2020

22. Yoshino A, Higuchi M, Salonga RB. Associations between social support and access to healthcare among Filipino women living in Aichi Prefecture. Nagoya J Med Sci. 2021;83(3) in print.

23. Shakya P, Sawada T, Zhang H, Kitajima T. Factors associated with access to HIV testing among international students in Japanese language schools in Tokyo. PLoS One. 2020;15(7):e0235659. https://doi.org/10.1371/journal.pone. 0235659.

24. Parikh N. Migrant health in Japan; safety-net policies and advocates' policy solutions. Asia Pac J Jpn Focus. 2010;8(12):3.

25. Yamanaka K. Migration, differential access to health services and civil society's responses in Japan. In: Santosh J, Toyota M, Yeo BSA, editors. Migration and health in Asia. London: Routledge; 2006. p. 141-60.

26. Sakamoto H, Rahman M, Nomura S, Okumoto E, Koike S, Yasunaga H, et al. Japan health system review. 8. 1. New Delhi: World Health Organization, Regional Office for South-East Asia; 2018. Available from: https://apps.who. int/iris/bitstream/handle/10665/259941/9789290226260-eng.pdf?sequence= 1 \&isAllowed =y. Cited 31 Mar 2021

27. Niwa M. Zainichigaikokujin no hoken.iryo.fukushi no hosyo to houtaikei [in Japanese] (Security and legal systems of health, medical and welfare for foreign residents in Japan). In: Lee S, editor. Zainichigaikokujin no kenkoshien to iryo tsuyaku: Darehitori torinokosanai tameni (Health support and medical interpretation for foreign residents in Japan: to leave no one behind). Tokyo: Kyorin Shoin; 2018. p. 45-9.

28. Gulliford M, Figueroa-Munoz J, Morgan M, Hughes D, Gibson B, Beech R, et al. What does 'access to health care' mean? J Health Serv Res Policy. 2002;7(3):186-8. https://doi.org/10.1258/135581902760082517.

29. Ricketts TC, Goldsmith LJ. Access in health services research: the battle of the frameworks. Nurs Outlook. 2005;53(6):274-80. https://doi.org/10.1016/j. outlook.2005.06.007.

30. Levesque JF, Harris MF, Russell G. Patient-centred access to health care: conceptualising access at the interface of health systems and populations. Int J Equity Health. 2013;12(1):18. https://doi.org/10.1186/14 75-9276-12-18.

31. Institute of Medicine Committee on Monitoring Access to Personal Health Care Services. Access to health care in America. Washington (DC): National Academic Press; 1993

32. Aday LA, Andersen R. A framework for the study of access to medical care. Health Serv Res. 1974;9(3):208-20.

33. Andersen RM, Davidson PL, Baumeister SE. Improving access to care. In changing the US health care system: key issues in health services policy and management. 4th edition. Edited by Kominski GF. San Francisco: JosseyBass; 2013.

34. Penchansky R, Thomas JW. The concept of access: definition and relationship to consumer satisfaction. Med Care. 1981;19(2):127-40. https:// doi.org/10.1097/00005650-198102000-00001.

35. OECD. Unmet needs for healthcare: Comparing approaches and results from international surveys: OECD; 2020. Available from: https://www.oecd. 
org/health/health-systems/Unmet-Needs-for-Health-Care-Brief-2020.pdf. Cited 9 Dec 2020

36. Pei L, Toyokawa S, Kobayashi Y. Labor factor barriers to seeking medical services among metropolitan workers: a cross-sectional analysis by sex using the J-SHINE study. J Occup Health. 2017;59(5):418-27. https://doi. org/10.1539/joh.16-0242-OA.

37. Aichi Medical Interpretations System, Aichi prefecture. Iryokikan nado gaikokujin taio manyuaru Soron [in Japanese] (A manual for medical institutions how to accept foreign patients General information). Nagoya: Aichi Medical Interpretations System, Aichi prefecture. Available from: http:// www.aichi-iryou-tsuyaku-system.com/manual/data/japanese/1/manual1-1a. pdf. Cited 9 Dec 2020

38. Tsutsumi K. Gaikokujin rodosya to sonokazoku heno iryoshien - Aichi-ken Toyota-shi no jirei wo chushin ni [in Japanese] (Medical support for foreign workers and their families - focusing on a case report in Toyota, Aichi). Reference. 2007;673:66-76. https://dl.ndl.go.jp/info:ndljp/pid/998823 ?tocOpened $=1$.

39. Japan Students Services Organization. Result of an annual survey of international students in Japan 2019: Japan Student Services Organization; 2020. Available from: https://studyinjapan.go.jp/en/_mt/2020/08/date2019z_ e.pdf. Cited 9 Dec 2020

40. Association for the Promotion of Japanese Language Education. Heisei-21nendo nihongo kyoikukikan gakuseiseikatsu jittai chosa [in Japanese] (A survey on the current living conditions of students studying in Japanese language institutes in Fiscal 2009). Tokyo: Association for the Promotion of Japanese Language Education; 2010. Available from: http://www.nisshinkyo. org/article/pdf/overview03.pdf. Cited 9 Dec 2020

41. "Hairisukusya no kekkaku taisaku" kenkyuhan ("Tuberculosis control for the high-risk populations" Research Group). Nihongogakko kekkaku kenshin no arikata ni kansuru teigen [in Japanese] (Recommendations of tuberculosis screening in Japanese language schools). Tokyo: The Research Institute of Tuberculosis, Japan Anti-Tuberculosis Association; 2017. Available from: https://jata.or.jp/dl/pdf/data/arikata_20180309.pdf. Cited 9 Dec 2020

42. Kawatsu R. Yunyukansensho toshiteno kekkaku [in Japanese] (tuberculosis as an imported infectious disease). Infect Agents Surveill Rep. 2017:38:234-5.

43. Japan Students Services Organization. Heisei-29-nendo shihi gaikokujin ryugakusei seikatsu jittai chosa [in Japanese] (a survey on the current living conditions of privately-funded foreign students in fiscal 2017). Tokyo: Japan Students Services Organization; 2019. Available from: https://www.studyinja pan.go.jp/ja/_mt/2020/08/seikatsu2017.pdf. Cited 9 Dec 2020

44. Sioson EP. Uneven integration: local government integration policies and Filipino residents in Nagoya City, Japan. Asia Pac Policy Stud. 2017;4(3):496513. https://doi.org/10.1002/app5.190.

45. Aichi Prefectural Office. Aichi-kennai no shichoson ni okeru gaikokujin juminsu no jokyo (Heisei-28-nen 12-gatsu matsu genzai) [in Japanese] (The number of foreign residents in Aichi Prefecture (as of the end of December, 2016)): Aichi Prefectural Office; 2017. Available from: https:/www.pref.aichi. jp/soshiki/tabunka/gaikokuzinjuminsu-h28-12.html. Cited 9 Dec 2020

46. Muhib FB, Lin LS, Stueve A, Miller RL, Ford WL, Johnson WD, et al. A venuebased method for sampling hard-to-reach populations. Public Health Rep. 2001;116(SUPPL. 1):216-22. https://doi.org/10.1093/phr/116.S1.216.

47. Nomura Y, Poudel KC, Jimba M. Hard-to-reach populations in Japan. Southeast Asian J Trop Med Public Health. 2007;38(2):325-7.

48. Kobori E, Maeda Y, Yamamoto T. Mortality rates of foreign national residents in Japan: comparison with the Japanese population and a possible healthy migrant effect. Nihon Koshu Eisei Zasshi. 2017;64(12):707-17. https://doi. org/10.11236/jph.64.12_707.

49. Miller R, Tomita Y, Ong KIC, Shibanuma A, Jimba M. Mental well-being of international migrants to Japan: a systematic review. BMJ Open. 2019;9(11): e029988. https://doi.org/10.1136/bmjopen-2019-029988.

\section{Publisher's Note}

Springer Nature remains neutral with regard to jurisdictional claims in published maps and institutional affiliations.

Ready to submit your research? Choose BMC and benefit from:

- fast, convenient online submission

- thorough peer review by experienced researchers in your field

- rapid publication on acceptance

- support for research data, including large and complex data types

- gold Open Access which fosters wider collaboration and increased citations

- maximum visibility for your research: over $100 \mathrm{M}$ website views per year

At BMC, research is always in progress.

Learn more biomedcentral.com/submissions 